\title{
Respect for the Sacred versus Freedom of Expression: Analysis from an Islamic Perspective in the Context of De-Radicalization
}

\author{
Recep Dogan ${ }^{1}$ \\ ${ }^{1}$ Wisdom College, Brisbane, Australia \\ Correspondence: Recep Dogan, Wisdom College, Brisbane, Australia.
}

Received: February 8, 2018

Accepted: March 5, 2018

Available online: March 15, 2018

doi:10.11114/ijsss.v6i5.3002

URL: https://doi.org/10.11114/ijsss.v6i5.3002

\begin{abstract}
Freedom is the most basic of rights that every human being is born with. Freedom of expression is one of the essential elements of a democratic society. Although in a liberal democratic society freedom of expression is an essential right there are some concerns that if it could cause harms to others when used without any limit. In this regard, all human beings expect respect for their sacred and this seems to be the only way to build a peaceful society. Because, if the sacred of people are humiliated through media, newspapers, cartoons, or any other means this creates enmity and hatred towards certain faiths and in return, the humiliated ones develop anger, violence and terror towards to abusers of their faiths. This article aims to examine whether freedom of expression should be limited when criticizing the sacred, and also seeks to analyze if respecting for the sacred can be a solution towards the process of de-radicalizing religious extremism. Finally, this article emphasizes on the necessity of interfaith dialogue among people from different faiths to promote peace in the world.
\end{abstract}

Keywords: respect for the sacred, freedom of expression, hate speech, de-radicalization, preventing evil means which cause hatred and enmity among people, interfaith dialogue

\section{Introduction}

\subsection{Freedom of Expression}

Freedom is a right that allows people to live however they wish and do whatever they want to do as long as they do not harm others. Humankind should be free from all shackles which hinder them from making progress. Freedom of expression is a right of people to seek, receive, and impart information and ideas of all kinds either orally, in writing, in print, in the form of art, or through any other medium of one's choice (Claudia et al. 2016). Major faith traditions aim to secure basic human rights by their teachings. For example, freedom of faith, life, reproduction, mental health, and personal property are basic essentials in Islam which must be preserved for all people.

Although freedom and other human rights are universally accepted, their protection is left to governments in the world. Usually, some political, social and security problems have been used to justify an authoritarian worldview in some countries (Grossman, 2012). Freedom of expression is not an absolute right therefore the International Covenant on Civil and Political Rights (ICCPR), the American Convention (ACHR) and the European Convention on Human Rights (ECHR), include grounds of limitation through which states can legally limit it when it is necessary in a democratic society (Buyse, 2014. pp. 779-797).

Although a liberal democratic society requires freedom of expression this should be limited when it causes discrimination, hatred and prejudice against a certain faith or culture. People are free to determine how to live their own life. However, they achieve a better existence by respecting others within a society and this requires that they adjust and limit their freedom according to the criteria of social life (Gülen, 2006). Freedom of expression may cause violence if the sacred of people is humiliated through media, newspapers, cartoons, or any other means. This perspective may help policy makers to approach it in a more scientifically-grounded way.

Freedom of expression is not an impenetrable fortress but rather a flexible notion that can be balanced according to universal human values and rights. One of the key aspects of freedom of expression is the relation between rights and duties from a legal perspective. Usually, legal agreements articulate freedom of expression as linked to duties and responsibilities. In the human rights treaties, the potential dangers of freedom of expression were acknowledged, 
especially if it has the potential to lead to violence and hatred. However, there is no universally accepted criteria that clearly measures and determines it.

The relationship between violence and freedom of expression is one of the most difficult topics that has long been debated. In order to establish the connection between violence and expression, the former (violence) must be actual or the means which lead to violence is known from the previous experiences. Additionally, there should be a clear link between how violence is actively framed by the expression and how the audience is motivated by it. One of the methods that helps us to understand if an expression has caused violence is examining a text, speech, blog or radio/TV broadcast and whether a specific group or faiths is explicitly discriminated, humiliated or blamed and subsequently has become a victim of hatred and enmity.

\subsection{Radicalism Triggered by Fear and Hate Speech}

The stereotype approach to radicalism, including seeing all Muslims as potential radicals, diminishes the chance to resolve the claimed conflict with peaceful methods and provides an opportunity to radical terror groups to propagate their agenda among angry masses. They may argue that the west labels all Muslims as radicals and Islam as source of radicalism. This argument has potential to trigger feelings of revenge among Muslims. In order to defend their religion and Islamic identity ignorant minds may resort into violence and terror. However, if they can find a voice in media which expresses Islam and Muslims properly and respectfully their feelings would be subdued. Thus, radicals, extremists and terrorist groups must be identified clearly and separated from the majority of Muslims. With this approach, the west can get support from the majority Muslims in combatting radicalism and terrorism.

The other form of expression that contributes to radicalism is fear speech. In fear speech, a certain group is labelled as a threat to a nation or all people that it would attack them with the aim of extermination. For example, a politician may state that Muslims will destroy the United States and its values; thus, they must be prohibited from entering the State. Donald J. Trump, the president of USA, called for a complete and total shutdown of Muslims entering the United States (Page, 2015. 30 of Donald Trump's wildest quotes. Retrieved from

http://www.cbsnews.com/pictures/wild-donald-trump-quotes/3/).

In different occasions, he has made fear speech including;

we have a problem in this country; it's called Muslims,

he pledged to kick out all Syrian refugees for they might be ISIS,

he stated that if you have people coming out of mosques with hatred and death in their eyes and on their minds, they are going to have to do something, and

we have people out there that want to do great destruction to our country (Johnson \& Hauslohner, 2017. I think Islam hates us: A timeline of Trump's comments about Islam and Muslims. Retrieved from https://www.washingtonpost.com/news/post-politics/wp/2017/05/20/i-think-islam-hates-us-a-timeline-of-trumps-comm ents-about-islam-and-muslims/?utm_term=.86fd467e62d1).

With fear speech violent action against a specific group or faith is legitimized as a form of self-defense against a claimed danger. Therefore, although freedom of expression is a core value of democratic societies, it should be balanced from a human rights perspective to prevent violence and hatred towards certain groups or faiths. The right to life, religion and other universal values are to be protected against freedom of expression. Free speech must never threaten people's lives or freedom of religion. This point will be elaborated more in the following sections.

\section{Cartoon Violence and Freedom of Expression}

Modern democratic rights are subject to some limitations including freedom of speech and the law reflects an equilibrium point between freedoms and the harmful behavior of others. Prevention of harm is the main goal that involves analysis where different rights, benefits and policy objectives are weighed up against each other.

In a democracy, rights are not divinely bestowed. They are supposed to be inalienable. For a majority of countries, democratic rights and responsibilities are determined by parliaments which are elected by the citizens of a state. Rights are protected by constitution in some countries, and the law is not in conflict with it. The law and its application are upheld and overseen by courts. The separation of powers is necessitated due to the risk of potential abuse of power by any governmental institution against citizens.

A constitution or a bill of rights affords an additional layer of protection for minorities. Additionally, an international law framework serves to set minimum standards to protect universal human rights. However, when it comes to respecting for the sacred, there is a gap in which some extremists exercise freedom of expression (hate/fear speech) like by burning the Qur'an or humiliating Prophet Muhammad through cartoons. This creates enmity and hatred towards certain faiths and in return, the humiliated ones develop anger, violence and terror towards to abusers of their faiths. 


\subsection{Using Cartoon for Political Purposes}

The cartoon has a long history. One may argue that people of the Stone Age were the first to draw pictures of some unpopular chieftain to criticize them and their ruling (World Affairs Council, 2018. Understanding the World of Political Cartoons. Retrieved from

https://www.world-affairs.org/wp-content/uploads/2013/10/2003-Understanding-Political-Cartoons.pdf). Similarly, the Roman soldier of 79 A.D. scratched on the wall of his barracks in Pompeii a portrait of some harsh commanders to jab at them ((World Affairs Council, 2018. Understanding the World of Political Cartoons. Retrieved from https://www.world-affairs.org/wp-content/uploads/2013/10/2003-Understanding-Political-Cartoons.pdf). There is a rude caricature from the Roman period which ridicules a Christian by showing him at the foot of a crucifix upon which is impaled Jesus with the head of an ass (Keane, 2008).

The cartoon has been employed frequently and effectively as an aid in building up resistance to the policies of politicians (Keane, 2008). The invention of the printing press in 16 century made cartoons more effective to shape public opinion. The English artist William Hogarth (1697-1764) is usually considered the first cartoonist in Western history, and was also the first political cartoonist (Harrison, 1981). Political cartoons spread out in London first as a form of social protest and political persuasion and eventually around the world (Harrison, 1981).

During the time of Benjamin Franklin, Paul Revere and Abraham Lincoln hundreds of cartoons appeared for political purposes. Since Lincoln, cartoonists have used their skills to attack, criticize, humiliate, insult as an expression of their views on the most urgent political issues of the day (Harrison, 1981). In the 19th century cartoons were posted on walls, passed from person to person and published in newspapers and magazines. At the beginning of the twenty-first century, political cartoons appeared in a wide range of online publications which created controversy, enmity, hatred and bitter disputes. Anti-Semitic cartoons were prevalent throughout the twentieth century and Jews were the victims of ridicule and hatred (Goodwin, 2001). For long time Jews were portrayed as demons throughout Europe.

The conflict between freedom of expression and respect for the sacred appears in different forms in different parts of the world. On 30 September 2005, twelve cartoons of the Prophet Muhammad were published in the Danish newspaper Jyllands-Posten for the intention of encouraging tolerance among Danish children through better understanding of the tenets of Islam (Post, 2007). However, the cartoons were very offensive to followers of Islam and the question that needs to be answered here is why would someone deliberately present information to children about another religion in a very offensive way (Carens, 2006). Don't they know basic principles of Islam or do they simply want to offend Muslims? Initial reaction to the publications was peaceful protest involving approximately 3,500 protestors in Copenhagen (Saloom, 2006). A group of Muslims requested a meeting with Danish foreign minister to discuss the issue with the aim of preventing polarization of people in the society, but this request was refused. The lack of official response led Danish Muslim groups to reach out and internationalize their protest (Anderson, 2016).

\subsection{Debasing the Sacred Through Cartoon}

Sometimes, basic human rights can be practiced against each other. For example, freedom of expression can be used against the respect for the sacred. Debasing religious values or religious leaders through various means of expression may cause violence amongst people in a society.

It is alleged that there was a connection between the cartoons of Prophet Muhammad in the Danish newspaper Jyllands-Posten in 2006 and the attack on the Danish embassy in Islamabad, Pakistan, in June 2008 (Declan, 2008). The Swedish cartoonist Lars Vilks draw a cartoon showing the Prophet Muhammad's head in a very humiliating way and it was published by Nerikes Allehanda newspaper on 18 August, 2007 (BBC News, Swedish Cartoonist Gets Protection. Retrieved from http://news.bbc.co.uk/2/hi/middle_east/6999652.stm). Upon this, Abu Omar al-Baghdadi, head of Al-Qaida in Iraq, offered a reward of $\$ 100,000$ to anyone who could kill him. Due to the increasing tension among people from different faiths, the Swedish Prime Minister called for mutual respect between Muslims, Christians and non-religious groups to try to avert a wider conflict in the country (Keane, 2008). Obviously, Baghdadi is more extreme than the disrespectful Swedish cartoonist for Islam never permits any Muslims to kill any person on the pretext of cartoons depicting Prophet Muhammad. However, the initial provocation by the cartoonist caused the worse deed, thus, I argue that such evil means could be blocked from the beginning.

More recently, the French magazine Charlie Hebdo was attacked by terrorists on January 72015 in Paris upon publishing controversial cartoons depicting Prophet Muhammad (Silva, 2015. Charlie Hebdo Attack: The Prophet Muhammad Cartoons That May Have Caused Paris Magazine Massacre. Retrieved from http://www.ibtimes.com/charlie-hebdo-attack-prophet-muhammad-cartoons-may-have-caused-paris-magazine-1775898 ). Armed with assault rifles and other weapons, the terrorists killed 11 people and injured 11 others in the building. Nothing justifies or legitimizes the killing of civilians. All terror attacks and violence must be condemned without any reservation or condition. However, there are many less educated people among Muslims who are inclined to radicalism 
and extremism on the pretext of humiliating their sacred. In order to prevent or minimize the terror or radicalization among Muslims their sacred should not be humiliated, otherwise, radicalization in the Islamic world may increase and get worse.

In an international meeting of the Organization of the Islamic Conference (OIC) in Mecca, it is stated that Muslims have great concern about the rise of hatred against Islam due to the incident of desecration of the image of Prophet Muhammad (Saloom, 2006). The institution called on the United Nations to intervene and apply a binding resolution to prevent contempt of religious beliefs.

Instead of empathizing with the feelings of Muslims towards the published cartoons in various magazines, the right media in Europe approached to the matter critically (Saloom, 2006). This attitude increased the reaction against cartoonists and magazines in the Muslim world at large. Cartoonists acted irresponsible, because, they triggered the feelings of anger among Muslims by humiliating their sacred. I seek an answer for the question that if it was worthy to plant the seeds of hatred by disrespecting the sacred for the sake of freedom of expression.

In response to the growing racism, many European countries have regulated that all forms of racial discrimination is an offense whereby "a group of people are threatened, insulted or degraded on account of their race, color, national or ethnic origin, religion or sexual orientation" (Boyle, 2006. pp. 185-189). However, they do not consider that the satirical caricatures of Prophet Muhammad are an infringement for their constitutions and basic human rights (Keane, 2008). They believe that the cartoons depicted an individual (Prophet Muhammad) therefore, it could not be taken as degrading or insulting all Muslims. This approach is deprived of empathy for Prophet Muhammad is very important religious leader for all Muslims around the globe.

The UN Special Rapporteur Doudou Diène considers the cartoons as racist. He argues that the cartoons illustrated the increasing emergence of the racist and xenophobic currents in everyday life, and the political atmosphere in some European countries contributed to a context of the emergence of strong racist and extremist political parties (UN News Centre, 2006. Racism and Racial Discrimination on Rise around the World. Retrieved from http://www.un.org/apps/news/story.asp?NewsID=17718\&Cr=racis\&Cr1). Previously, he produced a report on Defamation of Religions and Global Efforts to Combat Racism. In this report, he stated that Islamophobia had two characteristics: "the intellectual legitimization of hostility towards Islam and its followers, and the political tolerance of such hostility in many countries (Diène, 2004. Special Rapporteur on Contemporary Forms of Racism, Racial Discrimination, Xenophobia and Related Intolerance: Addendum, Defamation of Religions and Global Efforts to Combat Racism: Anti-Semitism, Christianophobia and Islamophobia. 61st Sess., Provisional Agenda Item 6, U.N. Doc. E/CN.4/2005/18/Add.4). He believes that persistent Islamophobia in the media causes more radicalization toward Muslims.

Combatting the defamation of religions is one of the agenda of the UN Human Rights Commission, and their focus has been largely over the negative experience of Muslims in Europe (Keane, 2008). In the annual report in 2006, Diène focused on the situation of Muslims and Arab peoples in various parts of the world, with a section entitled "The Cartoons of the Prophet Muhammad Published in a Danish Newspaper." (Diène, 2004). He strongly criticized the publishers of the Danish cartoons in an international legal document for they practice unlimited freedom of expression which harms international norms that seek an appropriate balance between freedom of expression and religious freedom (Diène, 2004). He maintains that the publication of the cartoons for the sake of freedom of expression has supported the idea of clashes among civilizations in some intellectual, media and political circles (Diène, 2004). As a new approach, it can be suggested that cartoonists can use their influence to promote peace and understanding among different faiths and cultures; because, cartoons have a special role in forming public opinion.

The right to freedom of expression carries special duties and responsibilities. Although it is a democratic right to express ideas, it is a duty to prevent racist ideas targeting certain groups on the basis of their religious and ethnic origins. Thus, the ICCPR (International Covenant on Civil and Political Rights) stated that "any advocacy of national, racial or religious hatred that constitutes incitement to discrimination, hostility or violence shall be prohibited by law." (International Covenant on Civil and Political Rights, 1966. G.A. Res. 2200 (XXI), U.N. GAOR, 21st Sess., Supp. No. 16, art. 20).

\subsection{Cartoon from an Islamic Perspective}

Islam forbids any depiction of the Prophet; therefore, the cartoons are considered blasphemous by Muslims. Although there is no explicit chapter or text in the Qur'an and Sunnah regarding the prohibition of images of the Prophet, some scholars use the following arguments as evidence to prohibit Muslims from images and paintings;

Angels (of mercy) do not enter a house that has a picture in it (Bukhari, 1997).

The people who will receive the severest punishment from God will be the picture makers (Bukhari, 1997). 
Aisha (the wife of the Prophet) had a thick curtain (having pictures on it) and she screened the side of her house with it. The Prophet said to her, remove it from my sight, for its pictures are still coming to my mind in my prayers (Bukhari, 1997).

The makers of pictures (of living beings) will be punished on the Day of Resurrection, and it will be said to them, give life to what you have created (Bukhari, 1997).

Although images and paintings are allowed as long as they do not contradict basic principles of Islam there is a general consensus among Sunni scholars on the prohibition of the images of the Prophet. Because, images or paintings are not proper way to represent the Prophet's personality. Some contemporary scholars, mainly orientalists, argue that there is nothing that prevent Muslims from drawing pictures of the Prophet (Boyle, 2006). However, this does not change how Muslim scholars understand and interpret their own religious texts, and how Muslims perceive the cartoons. Indeed, according to Islam the depiction of any prophet is prohibited because representations of all prophets are strictly forbidden. All prophets are considered best people and role models in Islam; thus, they deserve utmost respect. In summary, the cartoons are a great insult to many Muslims.

\section{Respect for the Sacred from Islamic Perspective}

Every human being is a vicegerent of God in Islam. God stated in the Qur'an; "Remember (when) your Lord said to the angels: I am setting on the earth a vicegerent..." (Qur'an 2: 30, trans. Unal, 2007). The angles were surprised for they predicted that human beings would cause disorder and corruption on the earth and shed blood therein. But, God told angles that they did not know the wisdom in that and then God taught names to Adam, the father of human kind. The knowledge of names was related to Humankind's capacity which has been seen in their discoveries, scientific findings, civilizations, cultures and all other progresses they have made throughout human history. The capacity of representing God on earth made human beings so unique and special. Every man and woman enjoy this honor. With this paradigm, human rights are higher objectives that Islam aims to achieve.

From a Muslim perspective, everything in the heavens and the earth is created for the benefit of humanity (Qur'an 45: 13, trans. Unal, 2007); therefore, Islam gives a high importance to human beings and never neglects their rights even if it is the rights of one person. All people are equal as the teeth of a comb in Islam (Al-Daylami, 1986) and discrimination based on race, color, age, nationality, or physical traits is strongly prohibited. (Bukhari, 1997). All rights are equally important for every individual and they cannot be ignored or sacrificed for the benefit of a society.

Respect for the scared in Islam can be analyzed from two main points; preventing means that lead to evil results, and promoting all means that contribute to human rights and world peace. Islam aims to establish healthy relations among the members of society even if they are from different faiths, cultures or ethnic groups.

When the Prophet emigrated from Mecca to Medina in 622 C.E., he signed a pact with the people of Medina ensuring the rights of citizenship for all minority groups there (Ibn Ishaq, 1955. pp. 231-233). The charter constituted an agreement between the Muslim, Jewish, pagan, and Christian groups, declaring them to constitute one nation and this formed the basis of a multi-religious state in Medina (Watt, 1956. pp. 227-228). This is a model from early Islamic history to establish the notion of respect for all faiths, races and groups. Moreover, in order to promote mutual respect and friendship among Abrahamic religions, God commanded Prophet Muhammad to engage in interfaith dialogue with the people of scriptures in the Qur'an;

Say (to them, O Messenger): "O People of the Book, come to a word common between us and you, that we worship none but God, and associate none as partner with Him, and that none of us take others for Lords, apart from God." If they (still) turn away, then say: "Bear witness that we are Muslims (submitted to Him exclusively)." O People of the Book (Jews and Christians)! Why do you dispute concerning Abraham (whether he was a Jew or a Christian), when both the Torah and the Gospel were not sent down save after him? Will you ever not use your reason? (Qur'an, 3:65. trans. Unal, 2007).

In line with this call Prophet Muhammad visited Christian churches and Jewish synagogues in order to foster understanding and put an end to the inter-religious enmity and hatred (Tabari, 1992). Once, at the funeral of a Jew, the Prophet Muhammad stood up to show his respect to people from other faiths (Bukhari, 1997). Similarly, in 628 C.E. a group of Christians from Najran (a place in southwestern Saudi Arabia) came to Medina to learn about Islam and during their stay they requested permission from the Prophet to perform their rituals in the masjid (place of worship for Muslims known also as a mosque) (Tabari, 1992). He granted their wish and hosted them in a friendly manner. They had a debate with the Prophet with regards to Jesus, Mary and Christian doctrines in the masjid before public. The Prophet presented them some logical arguments as well as several verses from Surah (a chapter) Al-'Imran (The Family of Imran) in the Qur'an about these issues. Although the Christians did not accept Islam with these arguments, the Prophet did not force them to convert, rather, he made a peace treaty with them which contained the following articles: 
Christians have the right to live in safety, their property will be protected, their churches will not be harmed, monasteries will not be closed and priests will not be impeded when performing their duties. Moreover, Christians will not be compelled to provide supplies for Muslims during times of war and it is not permitted to interfere with or interrupt Christian worship (Tabari, 1992).

The call for interfaith dialogue, made by Islam 14 centuries ago to the People of the Book (Christians and Jews), is still valid today and it shows how various consciences, nations, religions and books can unite on one essential concept and word of truth. Karen Armstrong stated the Qur'an taught that the People of the Book were to be respected, and within the Islamic empire Jews and Christians were allowed full religious liberty, as were the Zoroastrians, Buddhists and Hindus (Armstrong, 2001a. p. 43). This shows that interfaith dialogue is not limited to Abrahamic religions, rather religious progress is possible by expanding universally and in unison, and not by being separate from one another (Dogan, 2014a).

There is no place for repulsive manners, condemnation or rudeness in Islam when dealing with people from other faiths (Gülen, 2012). Unfortunately, contemporary terror groups such as ISIS or Al Qaeda use Islam and religious concepts to legitimize their violence. This creates fear and anxiety all over the world. Moreover, policy makers and politicians like Donald Trump adopt a proactive style when addressing the terror issue by labelling all Muslims terrorists.

Nevertheless, Islam encourages its followers to be patient when insults and disrespect are directed toward them. However, if such an insult or disrespect is directed towards God, His Messenger and the Qur'an, the feelings against the disrespect should be shown in a civilized fashion. Respect for the sacred is not just an individual right; rather it is the right of all Muslims, and all humanity. As the impact of disrespect for the sacred affects many individuals, it is not something which can be dismissed, disregarded or tolerated by a single individual on behalf of the rest. However, Muslims are required to act in a way that is in harmony with their belief and Islamic doctrines. In other words, Muslims should show their reactions within the boundaries of democratic rights without resorting to violence and terror.

Unfortunately, people witness different forms of extreme behaviors triggered by grudge, hatred, and animosity in different parts of the world. Humiliating the sacred of certain groups or faiths through cartoons or media in general is a counter provocative act. The contemporary scholar Fethullah Gülen holds that if somebody makes an insult against God, the Prophets and angels, he/she also is insulting all of the people who cherish these values (Gülen, 2014. p. 184). He argues that an insult related to certain issues disturbs not only Muslims but also others who believe the same doctrines (Gülen, 2014. p. 184). According to this approach, if a common article of faith among Abrahamic religions is humiliated by media or cartoonists, then 4 or 5 billion people are negatively affected from this disrespect. Although violence and terror are absolutely prohibited in Islam no matter what would be the reason, there are extremists among Muslims who may resort to terror as a response to the humiliation of their scared.

Usually, it is not a proper conduct for a person to comment on a field in which he has no knowledge. If a layman who never studied science severely criticizes scientific methods and discoveries, he/she will both expose himself/herself to ridicule and commit disrespect toward scientists. However, if a comment is related to the matters of religion, commentators should be more careful, because, people, mostly uneducated ones, are very sensitive with regards to their faiths; thus, it is a duty upon all humanity to show respect for the sacred of all faiths to prevent radicalism and extremism among people.

Unfortunately, some people are humiliating Islam through media or other means without having a sufficient knowledge on the topic. Showing disrespect for the sacred may elicit certain responses from some inflamed people, for the scale of the insult covers millions of people, and it is always possible that some people in such a large population will act upon their emotions. At this point we make mention of the Islamic principle "sadd al-dharā' $\vec{\imath}$ " and analyze the topic from this perspective.

\subsection{Blocking the Means (Sadd al-Dharā '̄)}

Respect for the sacred can be analyzed from the perspective of preventing means that lead to evil acts. Blocking the means is a concept which is used by Muslim jurists to prevent harm from people in a society. Sadd al-dharā'î is the Arabic expression which means blocking ways, means and reasons. The juristic definition of sadd al-dharā'i is blocking the means which would lead to bad or evil results (Dogan, 2014b. p. 215). The means get the same juristic value with their results; therefore, if a means leads to a forbidden act (haram) then it is forbidden; if it leads to permissible act (mubah) then it is also permissible. Both the means and the end may be good or evil, physical or moral, and the two need not necessarily be present simultaneously (Kamali, 2003. p. 269). The nature and value of the means is determined by the result it leads to and the intention of the perpetrator is not taken into account. This approach may help lawmakers of today in the west to develop regulations which can prevent polarization, racism and enmity in society.

As a main principle of Islam, Muslims are always supposed to be very careful about their words, attitudes, and 
behaviors. They should consider the consequences of their words and carefully refrain from sudden outbursts of emotion. The Qur'an forbids Muslims from disrespecting the sacred of other faiths to avoid conflict and clashes among civilizations;

"Do not (O believers) revile the things or beings that they have, apart from God, deified and invoke, lest (if you do so) they attempt to revile God out of spite and in ignorance." (Qur'an, 6:108. trans. Unal, 2007).

A means which leads to an evil result acquires the value of the evil result. In order to understand this Islamic principle better, the Quranic prohibition with regards to disrespecting to idol worshippers is given here. The Qur'anic text forbids Muslims from insulting idol worshippers to prevent the means to an evil result. Because, when the sacred of idol worshippers is humiliated or insulted they would humiliate the sacred of Muslims as a way of retaliation and this leads to enmity, hatred and clashes among people. Unfortunately, extremists and radicals among Muslims ignore this type of Islamic teachings. They only focus on arguments which allow Muslims to fight their enemy. In order to justify and legitimize their violence, they approach the Qur'an partially by picking verses which explain the rules of war. When doing this, they disconnect verses from their historical conditions and ignore the main principle which oblige Muslims to understand each verse according to the totality of the Qur'an and Islamic teachings. Indeed, with this approach any holy book can be source of violence and terrorism. Thus, it is a vital issue that any religious matter must be studied according to the totality of sources, evidences and principles.

According the verse quoted above, insulting idols or unbelievers is forbidden regardless of the actual result that such conduct may lead to. Similarly, the intention of the perpetrator is irrelevant to the prohibition under discussion on an objective basis that it is most likely to invoke the evil result (Abu Zahra, 1958. p. 228). Imam Shātibī (d. 1388 C.E.), an Andalusian Sunni Islamic scholar, holds that if the means violate the basic purpose of religion (i.e. protection of religion, life) they must be blocked;

"The Lawgiver (God) has legalized certain forms of conduct and prohibited others in accordance with the benefit or harm that they lead to. When a particular act or form of conduct brings about a result which is contrary to the objectives of the Lawgiver, then it must be prohibited" (Shātịīī, 1975).

According to the principle "blocking means that lead to an evil result" Muslims are required to protect the honor of their religion by respecting the sacred of others. If a Muslim insults others' deity, they will do the same. Therefore, Islam never commands or recommends believers to insult the idols and the sacred of others. Democracy, freedom of speech and secular life style are core values of western secularists, thus, Muslims should respect them to promote mutual understanding and peace between them. In a secular society, citizens are allowed to practice any religion or be agnostic or atheist. Everyone can promote his/her worldview through peaceful methods without humiliating the sacred of others.

Terry Jones is the pastor of Dove World Outreach Center, a small nondenominational Christian church located in Gainesville, $\quad$ Florida, USA (Christopher, 2013. Retrieved from http://www.gainesville.com/article/LK/20130715/News/604152126/GS/). He has been arrested in Florida after announcing plans to burn nearly 3,000 copies of the Qur'an on the anniversary of 9/11 (BBC News, 2015. US pastor Terry Jones held after threats to burn Korans. Retrieved from http://www.bbc.com/news/world-us-canada-24059408). He authored a book titled "Islam Is of the Devil" and has not become widely known until after announcing plans to burn copies of the Qur'an. Former U.S. Secretary of State Hillary Clinton labelled this act as outrageous and disgraceful. The commander of the International Security Assistance Force in Afghanistan, General David Petraeus said, "It is precisely the kind of action the Taliban uses and could cause significant problems" (Barnes \& Rosenberg, 2010. Petraeus Condemns U.S. Church's Plan to Burn Qurans. Retrieved from http://www.wsj.com/articles/SB10001424052748703713504575475500753093116).

President Barack Obama was asked on September 9, 2010, on ABC's Good Morning America about the Qur'an burning controversy and he said:

"You could have serious violence in places like Pakistan or Afghanistan. This could increase the recruitment of individuals who would be willing to blow themselves up in American cities or European cities. I just want him to understand that this stunt that he is talking about pulling could greatly endanger our young men and women in uniform who are in Iraq, who are in Afghanistan. I hope he listens and understands that this is a destructive act that he is engaging in" (Alexander \& Spetalnick, 2015. Obama says planned Koran burning is boosting Qaeda. Retrieved from http://ca.reuters.com/article/topNews/idCATRE68820G20100909?sp=true).

When we examine the statements of Obama and Hillary Clinton, we notice that they acted in a responsible way to block means that lead to an evil result. Insulting the sacred of Muslims hurts them deeply however, destroying buildings and places of worship in reaction to such insolence is unacceptable. Before resorting to offensive attitudes people from any faith need to consider the consequences of their acts. Although insulting faith, religion, and sacred values are seen as a 
form of freedom of expression, it bears the potential to boost radical terror groups. There should be an international agreement on respecting the sacred to prevent conflicts and clashes among people from different faiths.

At this point, Gülen states:

"There is serious need for making respect for the sacred a thought owned by the entire humanity and for evoking this feeling in everyone. If the principle of respecting others' sacred values - an important component of peaceful coexistence-is not observed, conflicts arising from such incidents of disrespect will make their presence felt as much more horrible and greater problems in today's globalized and shrunken world" (Gülen, 2014. p. 184).

In his life the Prophet showed respect for others and encouraged his followers to do the same. However, today some extreme groups are misinterpreting religion by being offensive to others. There is no room for hate and hostility in Islam nor in the life of its envoy Muhammad. In order to prevent radicalism among people, the international institutions on human rights should regulate an agreement in which respect for the sacred of all faiths is secured.

\subsection{Radical Islam, Media and Islamophobia}

Radical Islamic theory is built on the concept of theocracy along with enforcement. A state is ruled by the principles of the Sharia. According to radical Islamic groups, their views are the only truth and those who do not adopt their beliefs are considered outside of Islam, thus, killing them is permissible. With the claim of returning to pure Islamic faith that is established by Prophet Muhammad, radical Islamic understanding has become attractive for many Muslims, especially young ones who live in Western countries. This is most likely the reason why many young Muslims from Western countries have joined the ISIS terrorist group in spite of the groups' brutal violence and evil crimes against all humanity. The idea of resistance against Western forces in Islamic lands in order to establish the pure Islamic faith again is the main motivation for some Muslims to be radicalized.

Although radical groups represent marginal tendency in the Muslim world, their claims and methods to achieve them caused Westerners to understand jihad as encompassing indiscriminate acts of violence in the name of Islam (Kurucan $\&$ Erol, 2012). In order to protect one's faith, life, family, property and land against aggressors, Muslims can resort to physical force; however, this is one of the many meanings of jihad. In general, jihad is one's struggling against all destructive emotions such as rancor, hatred, jealousy, arrogance, pride, self-love, egotism and the evil-commanding self (Gülen, 1998.). In Prophetic traditions, jihad is conceptualized in a social context; a person who works for the good of widows and the needy is like those who fight in the name of God (Bukhari, 1997. Nafaqat, 1). Another form of jihad in prophetic tradition is speaking the truth to the face of a despotic and tyrannical ruler (Abu Dawud, 1984). Jihad also has a social and intellectual dimension in the context of exerting conscience and reason to derive a legal ruling from the sources, namely ijtihad (Kurucan \& Erol, 2012. p. 54.).

Some western scholars and right-wing media have failed to question their interpretation of Islamic concepts. Using Islamic terminology provocatively fuels terrorism. Because it decreases the gap between the marginal terrorist groups and the majority of Muslims and also reinforces the symbiotic relationship between Islamophobia and radicalization (Abbas, 2012). The language used by some right-wing media and politicians like Trump in the West provides a platform for radical groups to justify their evil acts in the eyes of some Muslims. As a stereotype, western depictions of Islam are distorted, seeing Islam as a religion of violence and terror (Antúneza \& Tellidisb. 2013). Perhaps, the major motivation for the crusades was this depiction of Islam. This approach still poses a threat to the national security in Western countries (Leeuwen, 2008) and creates an additional opportunity for radical groups to recruit Muslims who feel oppressed.

Due to the detrimental effects of such language used by some media and politicians, Westerners fear Islam and its followers for they see them as a threat to their most basic values. This fear feeds Islamophobia in the West, and in return, Islamophobia causes radicalization in the Islamic world. In order to solve this issue, Muslim scholars, community leaders, politicians and other effective people in the Muslim world should work together to educate ignorant masses, because by eliminating ignorance they will block the means which lead to radicalism. Additionally, the West, policy makers, media and politicians should support the effort of de-radicalization in the Muslim world by using respectful language in relevance to Islam and Muslims. When dealing with terrorism or extremism, they should avoid generalization and call only extremists as terrorists.

Radical terrorist groups use to their advantage the misconceptions that non-Muslims have, such as the hate and fear of Islam, and gather support for terrorist acts within the frame of defensive posture. Rather than targeting the few individuals who engage with radicalism, counter-radicalization policies in the West have had the effect of targeting the entire Muslim communities, hence becoming counter-productive (Antúneza \& Tellidisb, 2013). Moreover, Islamophobia and the negative approach to Islam in the West has caused some Muslims to become the victims of non-Muslims (Amir, 2007). 
Using Islamic concepts in a negative sense is very dangerous for the West, especially if it reinforces the idea that the West is an implacable enemy of Islam. Radical groups have managed to deceive some Muslim minds with the idea of West-East or cross-crescent conflict and confrontation. In order to convince them, they employed a conspiracy theory against the Islamic religion and way of life. Indeed, to a certain degree, they succeeded in their manipulative war propaganda against the West (Armstrong, 2001b). There are some legitimate reasons for Muslims to resent the West such as the colonial heritage, the consumerist lifestyle and Western arrogance. Nevertheless, majority of Muslims in Islamic world still oppose radical terror groups and their war propaganda.

Contrary to stereotypes, Islam advocates numerous non-violent and peacebuilding values, and expects Muslims to abide and live by them much like Christian doctrines (Antúneza \& Tellidisb. 2013). There have been extremists in almost every religion, yet this does not justify labelling all of its followers as terrorists. In countries where Muslims reside, some religious leaders and uneducated Muslims have no other weapon other than their fundamentalist interpretation of Islam, which they use to engage people in their evil agendas to serve their own purposes (Gülen, 2005).

The sources of terrorism in Islamic world are three; ignorance, disunity and poverty. Lack of pluralism and bitter conflicts among Islamic groups feed radicalism and terrorism. It is difficult to eliminate terror before solving these problems. Although the approach towards Islam in the Western media is mostly negative, it is not wise to blame them before recognizing the problems within Muslim societies. If one lacks sound knowledge however possesses bravery, then their bravery can lead such ignorant people to insanity or terrorist acts which may not be rectifiable. Therefore, the first step for eliminating terror in the world should be educating ignorant minds in Islamic world.

True Muslims will never allow themselves to be involved in terrorist activities. However, problems such as anti-democratic practices and human rights violations have resulted in the foundations of various disaffected and disenfranchised groups, and these ignorant people have been manipulated and used by terrorist groups to achieve their goals (Gülen, 2014). Moreover, they have based all of their efforts on destruction and the creation of fear in society.

No period of Islam witnessed the like of today's atrocities committed or so-called jihadist acts in the name of religion including suicide attacks, resulting in a mass murder of women, elderly, children, and all (Gülen, 2014. Retrieved from, http://www.herkul.org/weekly-sermons/the-grave-consequence-of-murders-committed-under-the-guise-of-religion-2/. Utilizing dissatisfied youths who have lost their spirituality and using them as murderers on the pretext of some evil goals is the main method for radical groups. Opposing to this, it would be good if moderate and open minded Muslim scholars and community leaders educate the youth and public in a compassionate and tolerant way.

\section{Conclusion}

Terrorism is ugly in its nature, and it must be addressed with a great deal of consideration. Governors and responsible officers should aim to find the motivating factors for radicalism and terror. In order to eliminate terror in the world Muslims and non-Muslims should work collectively, otherwise civilizations, civic organizations and nations will always be under threat.

Although freedom of expression is a right of people to think and express themselves, promoting world peace by blocking all means that cause enmity, hatred and fighting among people is a responsibility of all human beings. The freedom of expression may cause violence if the sacred of people are humiliated through media, newspapers, or any other means. Humiliating the sacred of certain groups or faiths through cartoons or media in general is counter provocative. We are all responsible for planting the seeds of respect for the sacred, as the repercussions of non-conformity to this ethos has wider more serious implications for entire humanity.

The stereotype approach to radicalism and including all Muslims as potential radicals diminishes the chance to resolve the claimed conflict with peaceful methods. Contrary to stereotypes, Islam advocates numerous non-violent and peacebuilding values, and expects Muslims to abide and live by them much like Christian doctrines.

Dialogue among faiths, cultures and civilizations is a must in a globalized world today. Dialogue is an exercise of learning about those who have different faiths and cultures. It is a learning process in relevance to how to coexist with people who subscribe to different beliefs, customs, and worldviews. Dialogue increases mutual understanding and good relations as well as breaks downs the barriers which lead to bigotry, suspicion and enmity.

In order to promote love, respect, mercy, peace and human rights, people from different faiths should engage in intercultural and interfaith dialogue. Moreover, radicalism and terrorism can be better prevented through interfaith dialogue for it fosters understanding towards each other among people from different faiths as well as develops respect for the sacred of all people.

Humankind cherish many common and universal values; thus, this necessitates dialogue. Indeed, it is the only solution for an expected clash between civilizations based on religious and cultural differences. The first step to establish dialogue is focusing on common values and abstaining from humiliating the sacred. Scholars, religious leaders, 
politicians and media should promote love and compassion among humanity for all living beings, because people become more exalted with compassion while they are disgraced with wrongdoing, oppression, cruelty and terrorism. Goodness, beauty, truthfulness, and being virtuous are the essence of humanity. People will ultimately find their essence which is achieving peaceful coexistence through intercultural and interfaith dialogue.

\section{References}

Abbas, T. (2012). The Symbiotic Relationship between Islamophobia and Radicalization. Critical Studies on Terrorism, 5(3), 345-358. https://doi.org/10.1080/17539153.2012.723448

Abu Zahra, M. (1958). Usul al-Fiqh. Cairo: Dār al-Fikr al-'Arabi.

Al-Daylami, A. S. (1986). Al-Firdaws bi-Ma thur al-Khitab. Beirut: Dar al-Kutub al-'Ilmiya.

Alexander, D., \& Spetalnick, M. (2010). Obama says planned Koran burning is boosting Qaeda. Retrived from http://ca.reuters.com/article/topNews/idCATRE68820G20100909?sp=true

American Convention, Supra Note 2, Art. 13(1). Retrived from https://www.oas.org/dil/treaties_b-32_american_convention_on_human_rights.pdf

Anderson, K. (2016). Remarks by an Idealist on the Realism of the Limits of International Law. Georgia: J. Int'l \& Comp.

Antúneza, J. C., \& Ioannis, T. (2013). The power of words: the deficient terminology surrounding Islam-related terrorism. Critical Studies on Terrorism, 6(1), 118-139. https://doi.org/10.1080/17539153.2013.765703

Armstrong, K. (2001a). Holy War: The Crusades and Their Impact on Today's World. New York: Anchor Books.

Armstrong, K. (2001b). The Battle for God: Fundamentalism in Judaism, Christianity and Islam. Glasgow: Harper Collins.

Barnes, J. E., \& Matthew, R. (2010). Petraeus Condemns U.S. Church's Plan to Burn Qurans. Retrieved from http://www.wsj.com/articles/SB10001424052748703713504575475500753093116

BBC News. (2007). Swedish Cartoonist Gets Protection. Retrieved from http://news.bbc.co.uk/2/hi/middle_east/6999652.stm

BBC News. (2007). Swedish Cartoonist Gets Protection. Retrieved from, http://news.bbc.co.uk/2/hi/middle_east/6999652.stm

BBC News. (2013). US pastor Terry Jones held after threats to burn Korans. Retrieved from http://www.bbc.com/news/world-us-canada-24059408

Boyle, K. (2006). The Danish Cartoons. Human Rights Quarterly, 24(2), 185-189.

Bukhari, A. A., \& Muhammad, I. I. (1997). Al-Jami Al-Sahih Al-Bukhari. Riyadh: Darussalam Publishers and Distributors.

Buyse, A. (2014). Words of Violence: Fear Speech, or How Violent Conflict Escalation Relates to the Freedom of Expression. Human Rights Quarterly, 36(4), 779-797. https://doi.org/10.1353/hrq.2014.0064

Carens, J. (2006). Free Speech and Democratic Norms in the Danish Cartoons Controversy. International Migration, 44(5), 33-36.

Claudia et al. (2015). Human Rights of Older People: Universal and Regional Legal Perspectives. [S.1.] : Springer.

Curry, C. (2013). Dove World sold, soon moving to Tampa Bay area. Retrieved from http://www.gainesville.com/article/LK/20130715/News/604152126/GS/

Diene, D. (2004). Special Rapporteur on Contemporary Forms of Racism, Racial Discrimination, Xenophobia and Related Intolerance: Addendum, Defamation of Religions and Global Efforts to Combat Racism: Anti-Semitism, Christianophobia and Islamophobia. U.N. ESCOR, Comm'n on Hum. Rts., 61st Sess., Provisional Agenda Item 6, U.N. Doc. E/CN.4/2005/18/Add.4.

Dogan, R. (2014a). Conflict Resolution Forms in the Life of Prophet Muhammad. The International Journal of Religion and Spirituality in Society, 4(2), 9-19.

Dogan, R. (2014b). Usul al-Fiqh Methodology of Islamic Jurisprudence. New Jersey: Tughra Books.

Goodwin, M. G. (2001). More than a Laughing Matter: Cartoons and Jews. Judaism, $21(4)$, 146. https://doi.org/10.1093/mj/21.2.146

Grossman, C. (2012). Challenges to Freedom of Expression within the Inter-American System: A Jurisprudential Analysis. Human Rights Quarterly, 34(2), 361-403. https://doi.org/10.1353/hrq.2012.0026 
Gulen, F. (2005a). Pearls of Wisdom. New Jersey: Tughra Books.

Gulen, F. (2005b). An Interview with Fethullah Gülen. Translated and edited by Zeki Saritoprak and Ali Ünal. The Muslim World, 95(3), 325-471.

Gulen, F. (2006). Essays, Perspectives, Opinions. New Jersey: Light.

Gulen, F. (2012). Reflections on the Qur'ān: Commentaries on Selected Verses. New Jersey: Tughra Books.

Gulen, F. (2014). Journey to Noble Ideals, The Broken Jug Series 13. New Jersey: Tughra Books.

Gulen, F. (2014). The Grave Consequence of Murders Committed under the Guise of Religion. Retrieved from http://www.herkul.org/weekly-sermons/the-grave-consequence-of-murders-committed-under-the-guise-of-religion2/

Harrison, R. P. (1981). The Cartoon: Communication to the Quick. California: Sage Publications.

Ibn Ishaq, M. (1955). Sirah al-Rasul al-Allah. Translated and edited by A. Guillaume. Oxford University Press: Karachi.

International Covenant on Civil and Political Rights, adopted 16 Dec. 1966, G.A. Res. 2200 (XXI), U.N. GAOR, 21st Sess., Supp. No. 16, art. 20, U.N. Doc. A/6316 (1966), 999 U.N.T.S. 171 (entered into force 23 Mar. 1976).

Johnson, J., \& Hauslohner, A. (2017). I think Islam hates us: A timeline of Trump's comments about Islam and Muslims. Retrieved from

https://www.washingtonpost.com/news/post-politics/wp/2017/05/20/i-think-islam-hates-us-a-timeline-of-trumps-c omments-about-islam-and-muslims/?utm_term=.86fd467e62d1

Kamali, M. H. (2003). Principles of Islamic Jurisprudence. Cambridge: Islamic Texts Society.

Keane, D. (2008). Cartoon Violence and Freedom of Expression. Human Rights Quarterly, 30(4), 845-875. https://doi.org/10.1353/hrq.0.0031

Kurucan, A., \& Mustafa, K. E. (2012). Dialogue in Islam. London: Great Britain.

Leeuwen, V. T. (2008). Discourse and Practice. Oxford: Oxford University Press. https://doi.org/10.1093/acprof:oso/9780195323306.001.0001

Martin, C., \& Diego, R. P. (2016). Human Rights of Older People: Universal and Regional Legal Perspectives. S. I: Springer.

Page, Jl. (2015). 30 of Donald Trump's wildest quotes. Retrieved from http://www.cbsnews.com/pictures/wild-donald-trump-quotes/3/

Post, R. (2007). Religion and Freedom of Speech: Portraits of Muhammad. Constellations, 14(1), 72-90. https://doi.org/10.1111/j.1467-8675.2007.00423.x

Saeed, A. (2007). Media, Racism and Islamophobia: The Representation of Islam and Muslims in the Media. Sociology Compass, 1(2), 443-462. https://doi.org/10.1111/j.1751-9020.2007.00039.x

Saloom, R. (2006). You Dropped a Bomb on Me, Denmark-A Legal Examination of the Cartoon Controversy and Response as it Relates to the Prophet Muhammad and Islamic Law. Rutgers Journal of Law and Religion, 3(1), 6.

Shatibi, I. I. M. (1975). Al-Muwafaqat fi Usul al-Shari'a. Egypt: al-Maktabah al-Tijariyah al-Kubra.

Silva, C. (2015). Charlie Hebdo Attack: The Prophet Muhammad Cartoons That May Have Caused Paris Magazine Massacre. Retrieved from

http://www.ibtimes.com/charlie-hebdo-attack-prophet-muhammad-cartoons-may-have-caused-paris-magazine-177 5898

Tabari, A. J., \& Muhammad, I. J. (1992). Jami al-Bayan an Ta'wil al-Qur'an. Beirut: Ālam al-Kutub.

UN News Centre. (2006). Racism and Racial Discrimination on Rise around the World, UN Expert Warns. Retrieved from http://www.un.org/apps/news/story.asp?NewsID=17718\&Cr=racis\&Cr1

Unal, A. (2007). The Quran with Annotated Interpretation in Modern English. New Jersey: Tughra Books.

Walsh, D. (2008). Bomb at Danish Embassy Kills Six in Pakistan. Retrieved from http://www.guardian.co.uk/world/2008/jun/03/pakistan.terrorism

Watt, W. M. (1956). Muhammad at Medina. Oxford: Clarendon Press.

World Affairs Council. (2018). Understanding the World of Political Cartoons. Retrieved from https://www.world-affairs.org/wp-content/uploads/2013/10/2003-Understanding-Political-Cartoons.pdf 
Yazir, H. (2007). Hak Dini Kur'an Dili. Istanbul: Azim Dagitım.

\section{Copyrights}

Copyright for this article is retained by the author(s), with first publication rights granted to the journal.

This is an open-access article distributed under the terms and conditions of the Creative Commons Attribution license which permits unrestricted use, distribution, and reproduction in any medium, provided the original work is properly cited. 